\title{
Effect of Workplace Bullying on Turnover Intention of Faculty Members: A Case of Private Sector Universities of Khyber Pakhtunkhwa, Pakistan
}

\begin{abstract}
Mariya Razzaghian ${ }^{1}$, Usman Ghani ${ }^{2}$
Abstract

Bullying behaviors are complex acts, and are believed to be more prevalent than sexual harassment. When organizations do not systematically address these behaviors, it results in a dysfunctional atmosphere where employees quit the organization(s), either voluntarily or by force. The twofold objectives of this paper were to measure the overall level of bullying prevalent within the sample and the relation between exposure to bullying behaviors and intention to quit that workplace. A total of 207 questionnaires were distributed among the faculty members of private sector universities of Peshawar. Both exposure to Workplace Bullying and Intention to Quit were separately measured. The level of workplace bullying was found to be low but a significant positive relationship was found between workplace bullying and intention to quit.
\end{abstract}

Keywords: workplace bullying, intention to quit, mistreatment, harassment, stress.

\section{Introduction}

In depth studies regarding workplace bullying and its detrimental effects on those exposed as well as for the organizations have been conducted in several countries across the globe. But to the authors' knowledge not much work has been done in this domain in Pakistan and especially Peshawar city. The city of Peshawar, being largest in the province of Khyber Pakhtunkhwa, is still bounded by its strong culture which it has inherited from the ancestral times. Therefore, the issue of bullying in the workplace is still not addressed on a broad spectrum and is more or less treated as a taboo.

The presence of many studies conducted on interpersonal aggression in the workplace is indicative of the fact that employees are in fact prone to various psychological and physical damages. It is also believed that continuous mistreatments have the potential to trigger violence among employees. However, not many studies have been conducted to capture the presence of these instances of exploitation which are in the form of indirect, passive and less obvious actions. Bullying has been recognized as a form of psychological abuse which is being faced by employees in various organizations in today's world. However, a detailed discussion on this issue is done

1. PhD Scholar, Institute of Management Sciences, Peshawar, Pakistan.

2. Assistant Professor, Institute of Management Sciences,Peshawar, Pakistan. 
in the following sections.

This paper aims to explore the construct of bullying in the workplace. It also highlights how this phenomenon constitutes the very discreet and subtle acts with negative consequences for the organizations as well as the victims. The first section of this paper pertains to the understanding of the core concept of bullying, and incorporating its definitions put forth by different researchers. It is followed by a discussion of its probable negative effects, both for the organizations and individuals. Finally, this paper presents the analysis, discussion and conclusion of its findings.

The rationale for this study is in fact to highlight and bring to surface the issue of workplace bullying along with the negative consequences it has for the organizations at large, which usually remain undetected. These negative effects are evident in the form of dissatisfied and low-morale employees, which leads to a reduction in their productivity. Academic institutions are entrusted with the responsibility of providing a healthy and educative atmosphere to the students studying there. Therefore, the presence of a fearful environment due to bullying is directly related to harming the potential of the faculty teaching there. This may also avert their energies from imparting education to protecting their self-image instead.

Faculty quitting or leaving their institutions due to facing or witnessing bullying in their workplace means increased costs for that organization in the form of recruitment, new hiring and training expenditures. The goodwill and reputation of that institution becomes also at stake. Such faculty members may speak about the atmosphere of that organization as negative and threatening, thus decreasing the chances of new members to apply for such an organization. This study, therefore, attempts to achieve the following two objectives. The first objective of this paper was to examine the level of workplace bullying prevalent in the private sector universities. The relation between exposure to bullying and intention to quit that workplace tested in academic universities of private sector in Peshawar city.

\section{Literature Review}

It was the era of 1980s when Heinz Leymann, a Swedish psychologist, started studying various forms of interpersonal work conflicts and used the term 'mobbing' to describe the hostility that was directed towards the employees at work. Later on, in the early 1990s, the term 'bullying' was used to describe the hostile behaviors at work by Andrea Adams, who was a British journalist. Ironically, bullying has no generally accepted definition and different terms have been used to refer to aggression in the form of bullying, for example, harassment (Brodsky, 1976), mobbing or psychological terror (Leymann, 1990), workplace trauma (Wilson, 1991), emotional abuse (Lut- 
gen-Sandvik, 2003) etc. Namie (2003, p. 16) defines bullying as a 'status-blind' hostile behavior that is intentional and repeatedly done. Namie \& Namie $(2003$, p. 3) have defined bullying as the 'repeated, malicious, health endangering mistreatment of one employee by one or more employees'. Bullying or mobbing is also defined as those situations in which the victim has to face long lasting, repeated and serious negative or hostile acts that not only oppress the victims but also annoys them (Leymann, 1996).

Vie, Glaso, and Einarsen (2011) called this phenomenon as an occupational stressor that has influenced 5\%-30\% of European workforce. Bullying in the workplace can also be declared as a form of psychological and domestic violence. Statistics have shown that it is three times more prevalent than sexual harassment (Namie, 2003) and involves deliberate humiliation of co-workers (Vega \& Comer, 2005). Accordingly, Coyne, Seigne, and Randall (2000) declare bullying as a form of counterproductive behavior at work. It has been estimated that one-fifth of all employees have experienced bullying and harassment in their workplaces (Godwin, 2008).

However, bullying does not refer to harmless incivility and teasing (Vega \& Comer, 2005). Speaking on the same lines, Yamada (2008) argues that a custom disagreement with a tough boss, having a difficult task to accomplish, or mere disagreements on job does not signify bullying behaviors. In the same manner, the involvement of parties with equal strength in a conflict like situation cannot be called as bullying. Bullying is a widespread issue which is not confined to any single occupational group. Similarly, it is not displaced towards any specific gender, age or organizational position. According to Einarsen, Hoel, Zapf, and Cooper (2003), for bullying to occur there should be an element of power difference between the victim and the bully. This difference in power can either stem out from hierarchical position in the organization or due to any other form of personal dynamics. Personal dynamics is referred to having an informal authority over somebody, for example, feeling superior in comparison to the other party due to being friends with an influential person in the workplace etc. (French \& Raven, 1968).

Generally, bullying acts are complex in nature because they refer to almost invisible and non-physical form of violence which can be overt or covert and has the potential to cause mild to severe harm. Irrespective of the manner these behaviors are conducted, such acts are done recurrently to inflict harm upon the person they are directed at. It can be manifested through many forms that includes (but is not confined to); shouting and yelling at the victim(s), criticism, socially excluding the victim(s), unrealistic work demands (Namie \& Namie, 2003), devaluing work related efforts or threatening the victim (Quine, 1999), ignoring the victim, refusing to talk or listen to the target, slander, laughter, scorn and acts of belittling the target, and negative gestures and glances (Vartia, 2001). In some instances, the victim is pressurized 
in order to make him/her feel frustrated (Kivimaki, Virtanen, Elovainio, Vahtera, \& Keltikangas-Jarvinen, 2003). It is important to remember that such incidents are repetitive and persistent in nature (Pate \& Beaumont, 2010) and typically occur on weekly basis (Einarsen \& Mikkelsen, 2003) and for prolonged periods, for example, six months (Einarsen 1999). Secondly, there exists a power imbalance either due to hierarchical position or physical power (Bowling \& Beehr, 2006).

As bullying is a malicious act, the victims that are subjected to such acts have to face harmful consequences. These negative and harmful effects include physical disorders, emotional problems and psychological injuries like low self-esteem, acts of aggression, fear, mistrust, isolation (Poilpot-Rocaboy, 2006), burnout (Matthiesen, Raknes, \& Rokkum, 1989), job dissatisfaction, job stress, intention to quit (Quine, 1999), stress, mood swings, loss of sleep, feelings of shame, embarrassment, and guilt and depression (Niedl, 1996). The physical disorders faced by the victims include stress headaches, high blood pressure, digestive problems, increased risk of cardiovascular illness and impaired immune system. It is also responsible for the occurrence of psychosomatic illnesses (Yamada, 2008) and musculoskeletal health complaints within the victimized individuals (Zapf, Knorz, \& Kulla, 1996). Moreover, as the episodes of bullying increase, the psychological, psychosomatic and musculoskeletal symptoms also increase (Einarsen, Raknes, Matthiesen, \& Hellesoy, 1996). Victims are also believed to show symptoms of Posttraumatic Stress Disorder and general anxiety disorder (Leymann \& Gustafsson, 1996). Suicidal ideation has been seen within extreme cases (Leymann, 1990).

Due to all these negative effects on health, the personal and social relationships of the victims are likely to suffer. Moreover, these negative outcomes are not related to victims or targets of bullying alone. Witnesses of these behaviors also suffer and their productivity may decline or get interrupted as they become more anxious when they hear about such incidents occurring to their colleagues (Andersson \& Pearson, 1999). A climate of fear prevails among them who think of themselves as the next potential victims of such hostile behaviors (Yamada, 2008).

The effects of bullying are not only limited to the victims or the witnesses. The organizations face heavy costs due to the prevalence of such behaviors. According to Bassman (1992), organizations can face direct costs in the form of medical and compensation claims by the targets due to stress they face on job because of bullying; costs of lawsuit; costs in the form of sick leaves and reduced productivity (Vega \& Comer, 2005), and loss of goodwill and reputation (Poilpot-Rocaboy, 2006). They may also face indirect costs that arise as a result of resentment and feelings of humiliation, all of which leads to absenteeism, poor customer-relationships, high turnover (Bassman, 1992) and loss of qualified personnel (Rayner, Hoel, \& Cooper, 2002). 
Neuman and Baron (1997) also argue that in organizations where the environment is filled with negativity, it makes the workers miserable, leading to more aggression, higher turnover rate and lower productivity.

According to Djurkovic, McCormack, and Casimir (2004), mistreatment of employees in the workplace leads to employees voluntarily quitting that organization. In a study by Rayner and Cooper (1997) conducted in the UK, 27\% of the bullied respondents left their jobs due to bullying. According to Namie (1999), on an average three out of four victims and witnesses of bullying are either driven out of the organization ultimately or they tend to quit that place themselves. Thus, loss of qualified personnel in the form of turnover (both voluntary and by force) adds to an increasing cost for the organization.

Lutgen-Sandvik (2003) highlights that when organizations do not systematically address these behaviors, it motivates the targets to engage in more of such behaviors through retaliation. This way further chances of aggression and violence are increased which accumulatively produce a dysfunctional culture within the organization (Heames \& Harvey, 2006). Overall, bullying causes alienation, un-employability, disaffection etc. in the society at large (Vega \& Comer, 2005).

\section{Methodology}

\subsection{Target Population}

Previous researches on workplace bullying have focused on university lecturers and other white collar employees in the public sector (see for example; Lewis, 2004; Bilgel, Aytac, \& Bayram, 2006). However, literature on private sector is scanty; hence, this study tries to target the private sector and contribute to the body of knowledge. Target population for this study was the teaching staff of academic universities within the private sector of Peshawar city. For this purpose, seven major universities (social sciences) in the private sector are chosen as the population of interest. This number covers almost all of the academic universities of Peshawar that are in the private sector. The aim was to cover the maximum number of faculty available in each university during the time this survey was conducted. In total, 207 questionnaires were distributed among the faculty members of these seven universities. Out of these, 190 questionnaires were returned after being filled by the respondents. This made the response rate for this study to be $91.78 \%$. However, 58 questionnaires had to be discarded due to improper filling. The mean age of the sample was 30.84 years. 


\subsection{Measurements}

Exposure to bullying: Exposure to bullying in the workplace serves as an independent variable of the study. It has been measured through the Negative Acts Questionnaire-Revised version (NAQ-R) which developed by Einarsen and Hoel (2001). This instrument has 22 items and the responses range from 'Never', to 'Now and Then', 'Monthly', 'Weekly' and 'Daily' (where, Never =1 and Daily = 5).

Intention to quit: Intention to quit was the dependent variable of the study. This variable measured using the Michigan Organizational Assessment Questionnaire by Cammann, Fichman, Jenkins, and Klesh (1979). It has 3 items and the options are based on a 5-point Likert scale, starting from 'Strongly disagree' to 'Strongly Agree' (where, Strongly Disagree $=1$ and Strongly Agree $=5$ ).

\subsection{Reliability}

The Cronbach's alpha for 22 items in the NAQ-R and the 3 items in the Michigan Organizational Assessment Questionnaire were 0.917 and 0.879, respectively.kl The values of both these reliabilities was above the minimum threshold of 0.7 , as is recommended by Nunnally (1978), stating a good level of reliability for both the scales.

\subsection{Regression Analysis}

To achieve the two objectives of the study, that is to measure the overall level of bullying in the target population, and to find the relationship between exposure to workplace bullying and the intention to quit, mean values were calculated and regression analysis is conducted. The choice of regression for the purpose of this study has been adopted from the work of Salin (2008). Also, the suitability of any statistical technique is primarily derived from the purpose of the analysis; and for the bivariate association identified in this paper, linear associations are accurate because with linear regression coefficients, the sum of components always correspond to the bivariate association (Hellevik, 2009).

\section{Results and Discussion}

For interpreting the overall level of workplace bullying faced, the numeric value 1 indicates the presence of very low levels of bullying $(1=$ Never$)$, while numeric value 5 indicates the otherwise, that is very high bullying $(5=$ Daily). Similarly, for the dependent variable, the numeric value 1 indicates very low intention to quit that workplace ( $1=$ Strongly Disagree) and numeric value 5 indicates a high level of intention to quit (5=Strong Agree). 


\begin{tabular}{|c|c|c|}
\hline Variables & Items & Cronbach Alpha \\
\hline Workplace bullying & 22 & 0.917 \\
\hline Intention to Quit & 3 & 0.879 \\
\hline
\end{tabular}

Table 1: Mean Values of Individual Items ${ }^{\mathrm{b}}$

\begin{tabular}{|c|c|c|c|c|}
\hline Items & $\mathrm{N}$ & Mean & $\begin{array}{l}\text { Std. Devia- } \\
\text { tion }\end{array}$ & $\begin{array}{l}\text { Std. Error } \\
\text { Mean }\end{array}$ \\
\hline \multicolumn{5}{|c|}{ Work place bullying $^{\mathrm{b}}$} \\
\hline $\begin{array}{l}\text { Someone is withholding information which } \\
\text { Effects your performance }\end{array}$ & 132 & 1.80 & 1.228 & .107 \\
\hline $\begin{array}{l}\text { Practical jokes are carried out by people you } \\
\text { don't get on with }\end{array}$ & 129 & 1.54 & .935 & .082 \\
\hline $\begin{array}{c}\text { You have got threats of violence or physical } \\
\text { abuse or actual abuse }\end{array}$ & 130 & 1.22 & .626 & .055 \\
\hline $\begin{array}{c}\text { You are being exposed to an unmanageable } \\
\text { workload }\end{array}$ & 130 & 1.89 & 1.189 & .104 \\
\hline $\begin{array}{l}\text { You are being the subject of excessive teasing } \\
\text { and sarcasm }\end{array}$ & 129 & 1.49 & .920 & .081 \\
\hline $\begin{array}{l}\text { You are pressurized not to claim something, } \\
\text { which by right you are entitled to(e.g., sick } \\
\text { leave, holiday entitlement, travel expenses) }\end{array}$ & 129 & 1.93 & 1.251 & .110 \\
\hline $\begin{array}{l}\text { Excessive monitoring of your work is carried } \\
\text { out }\end{array}$ & 127 & 2.23 & 1.393 & .124 \\
\hline Allegations are made against you & 130 & 1.45 & .827 & .072 \\
\hline $\begin{array}{l}\text { You are being given tasks with unreasonable } \\
\text { or impossible targets or deadlines }\end{array}$ & 130 & 1.79 & 1.098 & .096 \\
\hline $\begin{array}{l}\text { You are being humiliated or ridiculed in } \\
\text { connection with your work }\end{array}$ & 132 & 1.39 & .768 & .067 \\
\hline Your opinions and views are ignored & 129 & 2.03 & 1.098 & .096 \\
\hline $\begin{array}{l}\text { You have got persistent criticism of your work } \\
\text { and effort }\end{array}$ & 130 & 1.55 & .873 & .077 \\
\hline $\begin{array}{l}\text { You are being ignored or facing a hostile } \\
\text { reaction when you approach }\end{array}$ & 130 & 1.62 & 1.007 & .088 \\
\hline $\begin{array}{l}\text { You have got repeated reminders of your } \\
\text { errors or mistakes }\end{array}$ & 130 & 1.80 & 1.030 & .090 \\
\hline $\begin{array}{l}\text { You have received hints or signals from others } \\
\text { that you should quit your job }\end{array}$ & 128 & 1.69 & 1.202 & .106 \\
\hline
\end{tabular}




\begin{tabular}{|c|c|c|c|c|}
\hline $\begin{array}{l}\text { Intimidating behaviors such as finger-point- } \\
\text { ing, invasion of personal space, shoving, } \\
\text { Blocking/ barring the way are made }\end{array}$ & 131 & 1.46 & .888 & .078 \\
\hline $\begin{array}{l}\text { You are being shouted at or being the target } \\
\text { of spontaneous anger ( or rage) }\end{array}$ & 132 & 1.39 & .816 & .071 \\
\hline $\begin{array}{l}\text { Insulting or offensive remarks are being made } \\
\text { about your personal( i.e., habits and back- } \\
\text { ground), attitudes or your private life }\end{array}$ & 132 & 1.49 & .895 & .078 \\
\hline You are being ignored or excluded & 127 & 1.74 & 1.078 & .096 \\
\hline $\begin{array}{l}\text { You are being ordered to do work below your } \\
\text { level of competence }\end{array}$ & 131 & 1.76 & 1.053 & .092 \\
\hline $\begin{array}{c}\text { Gossips and rumors are being spread about } \\
\text { you }\end{array}$ & 132 & 1.59 & 1.070 & .093 \\
\hline $\begin{array}{l}\text { Your key areas of responsibility removed or } \\
\text { replaced with more trivial or unpleasant tasks }\end{array}$ & 129 & 1.69 & .991 & .087 \\
\hline \multicolumn{5}{|c|}{ Intention to quit $^{\mathrm{c}}$} \\
\hline I often think of leaving this organization & 132 & 2.86 & 1.230 & .107 \\
\hline $\begin{array}{l}\text { It is very possible that I will look for a new } \\
\text { job soon }\end{array}$ & 125 & 3.20 & 1.157 & .103 \\
\hline $\begin{array}{l}\text { If I may choose again, I will choose to work } \\
\text { for the current organization }\end{array}$ & 126 & 2.91 & .963 & .086 \\
\hline
\end{tabular}

Table 2: Overall Means of the Variables

\begin{tabular}{|c|c|}
\hline Variables & Overall mean \\
\hline Workplace bullying & 1.66 \\
\hline Intention to Quit & 3.02 \\
\hline
\end{tabular}

Table 3: Relationship between Workplace Bullying and Intention to Quit

\begin{tabular}{|c|c|c|c|c|}
\hline $\begin{array}{c}\text { Independent } \\
\text { Variable }\end{array}$ & $\begin{array}{c}\text { Dependent } \\
\text { variable }\end{array}$ & $\begin{array}{c}\text { Un-Standardized } \\
\text { co-efficient Beta }\end{array}$ & T value & Significance \\
\hline $\begin{array}{c}\text { Workplace } \\
\text { bullying }\end{array}$ & Intention to Quit & 0.734 & 7.965 & 0.000 \\
\hline $\mathrm{R}^{2}$ & 0.204 & & & 0.000 \\
\hline $\mathrm{F}$ & 33.390 & & & \\
\hline
\end{tabular}

In the first step, mean values of individual items and the overall mean values of the independent and the dependent variables are calculated, which are shown in Table 1 and 2 respectively. 
The overall mean value for workplace bullying (independent variable) prevalent within the private sector universities of Peshawar is found to be 1.66. Similarly, the overall mean value for intention to quit (dependent variable) among the faculty members working in these universities is found to be 3.02. Table 2 also shows that the prevalence figure for the overall level of bullying in the workplace is very low.

To test the relationship between independent and the dependent variables, regression analysis was used.

The table 3 also shows that the model fit is highly significant with a p-value of F-statistic at 0.000 ( $F$ value was found to be 33.390). This shows that the model is doing a good job in explaining the dependent variable, i.e. intention to quit. The value of $R^{2}$ is 0.204 (20.4\%). This value indicates that workplace bullying accounts for $20.4 \%$ variation in the dependent variable of 'intention to quit'.

The findings of this study revealed that exposure to workplace bullying indeed leads to "intention to quit" of those exposed. This finding is consistent with the findings of previous researchers and the work done in this domain (see for example, Neuman \& Baron, 1997; Djurkovic, McCormack \& Casimir, 2004; Rayner \& Cooper, 1997; Namie, 1999).

From the analysis of the data it is revealed that very low level of bullying is faced by the faculty members of the private sector universities of Peshawar. Bullying is mostly conducted through 'excessive monitoring of the work' followed by 'ignoring the views and opinions' of the faculty members. On the other hand, their overall intention to quit is relatively higher as compared to the overall level of bullying faced.

\section{Conclusion}

The study concludes that there exists a relationship between exposure to bullying in the workplace and intention to quit of those exposed. Therefore, letting go of such negative behaviors in the workplace as undetected places the credibility of such an institution, for the people working there, at stake. There is a need to be vigilant and attentive to such issues.

As discussed earlier, when employees are mistreated they may respond by quitting that workplace. Also, it has also been observed that mistreatment can cause un-employability in the society on one hand while it has also been observed by researchers that organizational mistreatment in the form of bullying usually goes unidentified. Therefore, this study expands the bullying literature by firstly adding that the bullying does exist in the educational institutions of Peshawar city of Pakistan and has the potential to cause the employees to quit. 
A limitation of this study is its cross sectional design and as a consequence the collection of data at one point in time. This limits the establishment of causality between the two variables of this study. Therefore, a longitudinal research should be carried out to establish the cause and effect relationship between workplace bullying (independent variable) and intention to quit (dependent variable), respectively.

This study did not directly take into account the possible role of gender in the relationship between bullying in the workplace and intention to quit. This role of gender can be quantitatively explored in future researches. Moreover, the role of personality as a mediating factor between being exposed to bullying and its negative consequences can also be explored. Personality is an important factor because the level of bullying experienced varies from individual to individual and hence its corresponding negative consequences delivered.

\section{References}

Andersson, L. M., \& Pearson, C. M. (1999). Tit for tat? The spiraling effect of incivility in the workplace. Academy of Management Review, 24(3), 452-471.

Bassman, E. (1992). Abuse in the Workplace: Management Remedies and Bottom Line Impact. Westport, Connecticut: Quorum.

Bilgel, N., Aytac, S., \& Bayram, N. (2006). Bullying in Turkish white-collar workers. Occupational Medicine, 56(4), 226-231.

Bowling, N. A., \& Beehr, T. A. (2006). Workplace harassment from the victim's perspective: A theoretical model and meta-analysis. Journal of Applied Psychology, 91(5), 998-1012.

Brodsky, C. M. (1976). The Harassed Worker. Toronto: Lexington Books.

Cammann, C., Fichman, M., Jenkins, D., \& Klesh, J. (1979). Michigan organizational assessment questionnaire. Ann Arbor, Michigan: University of Michigan.

Coyne, I., Seigne, E., \& Randall, P. (2000). Predicting workplace victim status from personality. European Journal of Work and Organizational Psychology, 9(3), 335-349.

Djurkovic, N., McCormack, D., \& Casimir, G. (2004). The physical and psychological effects of workplace bullying and their relationship to intention to leave: A test of the psychosomatic and disability hypotheses. International Journal of Organization Theory and Behavior, 7(4), 469.

Einarsen, S. (1999). The nature and causes of bullying at work. International Journal of Manpower, 20(1/2), $16-27$.

Einarsen, S., \& Hoel, H. (2001, May). The negative acts questionnaire: development, validation and revision of a measure of bullying at work. Oral presentation at the tenth European Congress on work and organizational psychology, Prague, Czech Republic. 
Einarsen, S., Hoel, H., Zapf, D., \& Cooper, C. L. (2003). The concept of bullying at work. In S. Einarsen, H. Hoel, D. Zapf \& C. L. Cooper (Eds.), Bullying and emotional abuse in the workplace. International perspectives in research and practice (pp. 3-30). London: Taylor \& Francis.

Einarsen, S., \& Mikkelsen, E. G. (2003). Individual effects of exposure to bullying at work. In S. Einarsen, H. Hoel, D. Zapf \& C. L. Cooper (Eds.), Bullying and emotional abuse in the workplace. International perspectives in research and practice (pp. 127-144). London: Taylor and Francis.

Einarsen, S., Raknes, B. I., Matthiesen, S. B., \& Hellesoy, O. H. (1996). Health aspects of bullying at work: Modifying effects of social support and personality. Nordisk Psykologi, 2, 116-137.

French, J. R. P., \& Raven, B. (1968). The bases of social power. In D. Cartwright \& A. Zander (Eds.), Group Dynamics: Research and Theory (pp. 259-269). London, UK: Tavistock Publications.

Godwin, K. (2008). Bullying and harassment: EOR Survey 2008. Equal Opportunities Review, 176, 17-24.

Heames, J., \& Harvey, M. (2006). Workplace bullying: A cross level assessment. Management Decision, 44(9), 1214-1230.

Hellevik, O. (2009). Linear versus logistic regression when the dependent variable is a dichotomy. Quality Eु Quantity, 43(1), 59-74.

Kivimaki, M., Virtanen, M., Elovainio, M., Vahtera, J., \& Keltikangas-Jarvinen, L. (2003). Workplace bullying and the risk of cardiovascular disease and depression. Occupational and Environmental Medicine, 60, 779-783.

Lewis, D. (2004). Bullying at work: The impact of shame among university and college lecturers. British Journal of Guidance $\mathcal{E}$ Counselling, 32(3), 281-299.

Leymann, H. (1990). Mobbing and psychological terror at workplaces. Violence and Victims, 5, 119-126.

Leymann, H. (1996). The content and development of mobbing at work. European Journal of Work and Organizational Psychology, 5(2), 165-184.

Leymann, H., \& Gustafsson, A. (1996). Mobbing at work and the development of post-traumatic stress disorders. European Journal of Work and Organizational Psychology, 5(2), 251-275.

Lutgen-Sandvik, P. (2003). The communicative cycle of employee emotional abuse: Generation and regeneration of workplace mistreatment. Management Communication Quarterly, 16(4), 471-501.

Matthiesen, S. B., Raknes, B. I., \& Rokkum, O. (1989). Bullying at work. Journal of the Norwegian Psychological Association, 26, 761-774.

Namie, G. (1999). The workplace bullying $\&$ trauma institute survey results. Presented at fourth interdisciplinary conference of American Psychological Association/National Institute for Occupational Safety and Health on Occupational Health and Safety, Baltimore, MD.

Namie, G. (2003). Workplace bullying: Escalated incivility. Ivey Business Journal, 1-6. 
Namie, G., \& Namie, R. (2003). The bully at work: What you can do to stop the hurt and reclaim your dignity on the job. Naperville: Sourcebooks Inc.

Neuman, J. H., \& Baron, R. A. (1997). Aggression in the workplace. In R. A. Giacalone \& J. Greenberg (Eds.), Antisocial behavior in organizations (pp. 37-67): Thousand Oaks, CA: Sage.

Niedl, K. (1996). Mobbing and well-being: Economic and personnel development implications. European Journal of Work and Organizational Psychology, 2, 239-249.

Nunnally, J. C. (1978). Psychometric theory (2nd ed.). New York: McGraw-Hill.

Pate, J., \& Beaumont, P. (2010). Bullying and harassment: A case of success? Employee Relations, 32(2), 171-183.

Poilpot-Rocaboy, G. (2006). Bullying in the workplace: A proposed model for understanding the psychological harassment process. Research and Practice in Human Resource Management, 14(2), 1-17.

Quine, L. (1999). Workplace bullying in NHS community trust: Staff questionnaire survey. British Medical Journal, 318(7178), 228-232.

Rayner, C., \& Cooper, C. (1997). Workplace bullying: myth or reality - can we afford to ignore it? Leadership and Organization Development Journal, 18(4), 211.

Rayner, C., Hoel, H., \& Cooper, C. L. (2002). Workplace bullying: What we know, who is to blame, and what can we do? London: Taylor \& Francis.

Salin, D. (2008). The prevention of workplace bullying as a question of human resource management: Measures adopted and underlying organizational factors. Scandinavian Journal of Management, 24(3), 221-231.

Vartia, M. (2001). Consequences of workplace bullying with respect to well-being of its targets and the observers of bullying. Scandinavian Journal of Work and Environmental Health, 27, 63-69.

Vega, G., \& Comer, D. R. (2005). Sticks and stones may break bones, but words can break your spirit: Bullying in workplace. Journal of Business Ethics, 58, 101-109.

Vie, L. T., Glaso, L., \& Einarsen, S. (2011). Health outcomes and self-labeling as a victim of workplace bullying. Journal of Psychosomatic Research, 70, 37-43.

Wilson, C. B. (1991). U.S. businesses suffer from workplace trauma. Personnel Journal, 47-50.

Yamada, D. (2008). Workplace bullying and ethical leadership. Journal of Values-bases leadership, 1(2), 49-62.

Zapf, D., Knorz, C., \& Kulla, M. (1996). On the relationship between mobbing factors, and job content, social work environment and health outcomes. European Journal of Work and Organizational Psychology, 5(2), 215-237. 